\title{
МЕТОДОЛОГІЧНІ ОСОБЛИВОСТІ ВИКЛАДАННЯ ТЕМИ “СЕПСИС" ВІДПОВІДНО ДО ВИМОГ БОЛОНСЬКОЇ ДЕКЛАРАЦІї
}

\author{
О. Ю. Іоффе, В. С. Кульбака, О. М. Коваленко, Ю. О. Супрун,
} М. М. Стець, Ю. П. Цюра

Національний медичний університет ім. О. О. Богомольия, м. Київ

\section{METHODOLOGICAL PECULIARITIES OF TEACHING THE THEME "SEPSIS" ACCORDING TO THE REQUIREMENTS OF BOLOGNA DECLARATION}

\author{
O. Yu. Ioffe, V. S. Kulbaka, O. M. Kovalenko, Yu. O. Suprun, M. M. Stets, Yu. P. Tsiura \\ National Medical University by O. O. Bohomolets, Kyiv
}

\begin{abstract}
У статті висвітлено методологічні особливості викладання теми “Сепсис"в умовах приєднання до Болонського процесу з врахуванням зміни концепції про сепсис як одну із форм синдрому системної запальної відповіді.
\end{abstract}

The article adduces the methodological peculiarities of teaching the theme "Sepsis" in conditions of joining the Bologna process taking into account the changes of conception about sepsis as one of the form of system inflammatory response syndrome.

Вступ. Реформування вищої медичної освіти після приєднання України до Болонського процесу та спрямовані на забезпечення гарантованої якості підготовки на принципах доказової медицини лікарів широкого профілю, які здатні ефективно і своєчасно вирішувати професійні завдання. Перехід до нової системи навчання потребує докорінної перебудови методичних заходів і методологічних принципів у підготовці лікарів нового покоління.

Мета роботи - вивчити і проаналізувати підсумки навчання студентів й опанування практичними навичками для удосконалення методичного забезпечення викладання теми “Сепсис".

Основна частина. Робота основана на аналізі якості навчання студентів, стійкості отриманих знань і набутих практичних навичок з теми “Сепсис". Проведено аналіз результатів поточного контролю i підсумкового модульного контролю (ПМК) серед 320 студентів медичного факультету № 1 і 180 студентів медичного факультету № 4.

Методичні розробки з теми “Сепсис" написані докладно, конкретно і відповідають вимогам реформованої вищої медичної освіти.

Опанування теми "Сепсис" студентами третього курсу відбувається на основі засвоєння патофізіологічних змін, котрі $€$ пусковими механізмами синдрому системної запальної відповіді (ССЗВ). В якості індивідуальної роботи один або два студенти презен- тують доповіді про значення ендогенних медіаторів у розвитку ССЗВ. Серед медіаторів запалення, яких нараховується більше 100 , розвиток ССЗВ частіше викликають екзотоксини, частини клітинної стінки бактерій, продукти метаболізму арахідонової кислоти, лейкотрієни, простагландини, тромбоксан, інтерлейкіни, оксид азоту, фактор некрозу пухлин. Студенти групи є активними учасниками презентації, ставлять запитання, доповнюють повідомлення доповідувачів. Це сприяє відновленню знань 3 базових дисциплін, а у студентів формуються здібності виступати перед аудиторією слухачів.

У методичних розробках кафедри, якими студенти широко користуються, чітко сформовані оптимальні клінічні і лабораторні критерії сепсису. Вони базуються на результатах консенсусної конференції Товариства критичної медицини і торакальних лікарів США (1993-1994 pp.).

За клінічними симптомами - тахікардія, тахіпное, температура тіла, лейкоцитоз або лейкоцитопенія, наявність порушення функції органів, гіпотензії, олігурії - студенти визначають різні септичні стани.

В доклінічних умовах, у навчальних кімнатах студенти опановують практичні навички або застосовують їх на рівні вміння: заповнюють системи для внутрішньовенного введення розчинів, на муляжах демонструють різні методи дренування, як один із профілактичних засобів сепсису. На стенді “Анти-

() О. Ю. Іоффе, В. С. Кульбака, О. М. Коваленко та ін. 
біотики" вивчають наявні на фармацевтичному ринку антибіотики, знайомляться із шляхами, дозуванням та кратністю введення препаратів у хворих на сепсис.

На стенді “Плазмозамінники” майбутні лікарі відновлюють знання з сучасних протишокових, дезінтоксикаційних засобів та препаратів парентерального живлення. В клінічних палатах, вивчаючи листки призначення, викладачі звертають увагу студентів на методику, дози застосування плазмозамінників у програмах комплексного лікування сепсису. Такий підхід сприяє мотивації до навчання та засвоєння матеріалу.

Методичною особливістю заняття є проведення практичного діагностичного тренінгу під час вивчення клініко-лабораторних даних хворих, котрі перебувають в Республіканському центрі лікування сепсису - базі кафедри загальної хірургії № 2 НМУ.

Ми звертаємо увагу на важливість висівання із крові, жовчі патогенних мікробів. На багатьох клінічних спостереженнях демонструємо, що діагноз сепсису базується на клінічних критеріях і не потребує виявлення збудника в крові.

Під час демонстрації хворих зосереджуємо увагу майбутніх лікарів на характер температурної кривої, на часті прояви септичного процесу в легенях, які $\epsilon$ головним органом-мішенню з розвитком пневмонії, гіпоксії, дихальної неспроможності, на виявлення симптомів, які свідчать про серцево-судинні розлади (тахікардія, гіпотонія, можливість розвитку інфекційного ендокардиту).

Ураження клаптів серця у хворих на сепсис, особливо в ін'єкційних наркоманів, спостерігається досить часто, перебігає атипово. Лікарі сімейної медицини мають бути налаштовані на діагностику цієї патології, направляти хворих на сепсис до спеціалізованих центрів і клінік для лікування.

У більшості випадків сепсису причинами його розвитку є гнійно-септичні захворювання м'яких тканин, тяжкі ускладнення захворювань (пневмонії, плеврити, перитоніти, перикардити, інфекційні ендокардити, остеомієліти та ін.). У кожного хворого потрібно виявити причину розвитку сепсису для прийняття лікувальних радикальних заходів з їі усунення.

Розглядаючи історії хвороби і лікування хворих на сепсис, закріпляємо знання та особливості антибіотикотерапії. Підкреслюємо значення раннього призначення антибіотиків до виділення та ідентифікації збудника. Коли є підозра на інфекційний процес або сепсис, потрібно призначити емпіричне парентеральне застосування антибіотиків двох різних груп. Після ідентифікації збудника доцільно застосовувати вузьконаправлені антибіотики. Студенти мають знати про можливість або необхідність використання антибіотиків резерву: ванкоміцину, таргоциду, тіснаму, меропенему та ін. Важливим $€$ тривала антибіотикотерапія, своєчасна заміна препаратів після втрати чутливості до них мікрофлори.

Студенти мають чітко усвідомити значення інфузійно-трансфузійної терапії, яка має бути цілеспрямованою, багатокомпонентною, поліфункціональною. Вона виконує дезінтоксикаційну функцію, підтримку кровообігу, корекцію вмісту білків, електролітів, кислотно-лужного балансу, зменшення наслідків тромбгеморагічного синдрому.

Хворі на сепсис потребують застосування багатьох лікарських засобів. Ми попереджаємо майбутніх лікарів про недопустимість одночасного внутрішньовенного введення комплексоутворюючих плазмозамінників (гемодез, неогемодез, неокомпенсан) 3 лікарськими засобами, на дію яких розраховує лікар (антибіотики, глікозиди та ін.). 3 ними в першу чергу утворюються комплекси, наприклад: полівінілпіролідон + антибіотик, які виводяться з сечею. При цьому втрачається активність обох лікувальних засобів.

Складні патогенетичні механізми пошкодження організму при сепсисі приводять до ураження ряду органів і систем. В основі цього пошкодження є гіпоксія, ішемія, яка виникає частіше всього внаслідок синдрому взаємного обтяження. При цьому порушується метаболізм, у тому числі окислення вільних жирних кислот, значне порушення синтезу АТФ. Одночасно накопичуються недоокислені продукти, які посилюють пошкодження мембран клітин, порушується функціонування катіонних насосів і т. д.

Лікування хворих на сепсис складне, багатопланове: застосування протеолітичних ферментів, “метаболічної терапії”'(глюкозо-калієві суміші, мілдронат, корекція вітамінного дефіциту, антиоксиданти), ентеросорбентів, кисневої терапії тощо. Під час практичного заняття студенти усвідомлюють, що дрібниць у лікуванні секпсису не бувас. Мають велике значення також правильне живлення і належний догляд за хворими.

Аналіз результатів поточного контролю і ПМК засвідчив, що студенти відповідально ставляться до навчання і якісно опанували тему “Сепсис".

Летальність серед хворих на сепсис за останні роки знижується, але залишається високою. Кращих результатів у лікуванні сепсису досягають лікарі спеціалізованих центрів і клінік. Останнім часом для інтенсифікації лікування септичних станів впроваджують такі нові високотехнологічні методи, як: ек- 


\section{ВДОСКОНАЛЕННЯ ВИЩОЇ МЕДИЧНОЇ ОСВІТИ}

стракорпоральна мембранна оксигенація, моноклональні антинейтрофільні антитіла, імуноглобуліни, анаболіки, кишкова деконтамінація, рекомбінантний інтерферон людини та ін.

Висновки: 1. Методологічними особливостями викладання теми “Сепсис" в умовах приєднання до Болонського процесу є врахування зміни концепції про сепсис як одну із форм синдрому системної запальної відповіді.

2. Практичний діагностичний та лікувальний тренінг у спеціалізованому центрі допомагає майбутнім лікарям якісно засвоїти матеріал теми, чітко уявляти свої дії у випадках лікування хворих із септичними станами.

На основі аналізу проведення практичного заняття були внесені корективи в методичні матеріали, в тому числі додані нові високотехнологічні методики лікування хворих на сепсис для поліпшення засвоєння теми “Сепсис", втілення отриманих знань і спостережень у майбутній практичній діяльності. 